nia wyjątkowo dobrze. Otrzymujemy bowiem książkę bogatą w aspekt poznawczy, dostarczającą licznych faktów i spostrzeżeń, jednocześnie nieforsującą swego stanowiska. Autorka nie rozstrzyga na przykład losów Marii w latach pięćdziesiątych i początku sześćdziesiątych — zbyt mało mamy tu informacji pewnych, a istniejące w obiegu wersje wydarzeń są z sobą sprzeczne.

Należy również docenić ogrom benedyktyńskiej niemal pracy włożony w przygotowanie tych listów do druku. Jednak - co cieszy niezmiernie — widoczny jest humanistyczny dar rozumnego i współczującego obchodzenia się z cudzym życiem. Życiem, które trudno nazwać — mając na względzie jego przebieg — nietypowym czy niezwykłym. Przedstawionym jednak w sposób godny podkreślenia i uznania.

Jędrzej Krystek

\title{
Дневники сотрудника НКВД: документальное разоблачение сталинизма, ред. Анастася Зеленкова, ИБИК, Рига 2019, cc. 256 [Wspomnienia funkcjonariusza NKWD. Dokumentalna analiza stalinizmu, red. Anastazja Zielenkowa, IBIK, Ryga 2019, ss. 256]
}

https://doi.org/10.19195/1429-4168.24.21

Przez pryzmat znanych nam faktów z życia osób, które chcemy lepiej poznać, kreślimy ich obraz. Nie wiedząc wszystkiego, nierzadko zbyt pospiesznie sporządzamy ich charakterystykę jako ludzi prawych lub wręcz przeciwnie - bez kręgosłupa moralnego, których działania wynikają z chęci osiągnięcia własnych korzyści, często kosztem innych. Niepełny obraz osób powstaje na skutek rozmaitych uwarunkowań zewnętrznych oraz celowego zatajania różnych faktów przez samych zainteresowanych. O ile przyczyny zewnętrzne są niezależne od jednostek, o tyle obraz kreowany przez nie same jest podyktowany chęcią bycia bohaterem lub lękiem przed krytycznym osądem otoczenia zarówno współczesnych, jak i następnych pokoleń. Uwarunkowania zewnętrze, miejsce i czas, sprawiają, że określone czyny są lepiej zrozumiałe dla tych, którzy musieli sprostać wyzwaniom podobnych sytuacji. Przeżycia, nierzadko traumatyczne, dotyczą zwłaszcza osób żyjących w czasach przewrotów politycznych i wojen, których uczestnicy musieli często dokonywać trudnych wyborów. Nie wszystkich było stać na odważne zachowania, ponadczasowo uważane za prawe. Jeśli ich działania na skutek zmiany sytuacji zewnętrznej po latach okazują się dyskusyjne, z reguły osoby te milczą o szczegółach swojej przeszłości. Jedną z takich osób jest bohater recenzowanej publikacji Иосиф Ятченя (Józef Jatczenia).

Autor wspomnień zdecydował się spisać koleje swego losu dopiero po przejściu na emeryturę. Jedną z przyczyn były pytania dotyczące wydarzeń z przeszłości, 
w tym jego losów, zadawane przez wnuka Władimira. Józef Jatczenia uznał, że dziecko ze swojej perspektywy, żyjąc w innych czasach i środowisku, nie zrozumie realiów minionego czasu i motywów jego postępowania. Przez okres 15 lat pisał, co widział i co było jego doświadczeniem, aby chłopiec, gdy dorośnie, uzyskał odpowiedzi na zadawane pytania. Należy dodać, że przez wiele lat tylko najbliżsi wiedzieli o bagażu przeżyć Józefa Jatczeni i podobnie jak on milczeli. Z recenzenckiego obowiązku wypada podkreślić, że choć wspomnienia oddane po latach do druku przez wnuka są świadectwem doświadczeń tylko ich autora, to jednak przez ich pryzmat możemy postrzegać losy pokolenia uwikłanego w wydarzenia końca lat Rosji carskiej, burzliwego czasu rewolucji, okresu krzepnięcia nowego państwa, czasu II wojny światowej i długich lat władzy sowieckiej. Prawdziwość historii opowiadanej przez Józefa Jatczenię potwierdzają, zamieszczone w drugiej części publikacji, dokumenty wydobyte $\mathrm{z}$ białoruskiego archiwum KGB.

Zwracając uwagę na wychowanie w rodzinie chłopskiej i lata dzieciństwa spędzone na wsi Zapole w rejonie iwacewickim obwodu brzeskiego, autor podkreśla, że przyzwyczaiły go one do ciężkiej pracy, nauczyły pewnego uporu — zdecydowania w dążeniu do osiągnięcia celu i przywiązania do tradycyjnych wartości. Dlatego nawet $\mathrm{w}$ najcięższych chwilach potrafił sobie poradzić $\mathrm{z}$ rozmaitymi wyzwaniami, imając się różnych zajęć. Jego nadrzędnym celem było przeżycie lub dążenie do polepszenia bytu, jaki był udziałem prostych ludzi. Zewnętrznym wyrazem hołdowania otrzymanemu wychowaniu była wierność jednej kobiecie, po której śmierci ożenił się powtórnie dopiero w 1986 roku. Trzeba dodać, że była to rzadkość w tamtych czasach, kiedy życie wielu osób było zaprzeczeniem kierowania się zasadami moralnymi. Choć na skutek okoliczności zewnętrznych naginał do rozmaitych wymogów codzienności swoje zasady, w chwili najważniejszej próby, chęci złamania w śledztwie, to właśnie zasady i wiedza zdobyta podczas służby w NKWD sprawiły, że oprawcy nie osiągnęli oczekiwanych rezultatów. Autor pozostał dla władz sowieckich do końca swoich dni „niepewnym elementem”. Ponieważ publikacja została wydana w małym nakładzie i niewiele osób może ją przeczytać, warto w kilku zdaniach przybliżyć jej treść.

Józef Jatczenia do 14. roku życia pracował w gospodarstwie rolnym ojca. Gdy rozpoczęła się wojna między Niemcami a Rosją, mając dość monotonii wiejskiego życia oraz coraz gorszego traktowania przez macochę, postanowił zaciągnąć się do wojska. W armii upatrywał szansy na inną, ciekawszą i lepszą przyszłość. Dzięki zakwalifikowaniu do służby urzędniczej w biurze sztabu nauczył się pięknej kaligrafii. Burzliwy czas wojny spowodował, że podupadł na zdrowiu. Na skutek uprzywilejowanego traktowania przez przełożonego jako chorowity młodzik został zwolniony z armii i znalazł zatrudnienie jako portier w liceum w Jarosławiu. Jak sam pisze, był to dostatni okres w jego życiu. Został wyposażony w solidne buty i ubranie, otrzymywał też stosowną zapłatę. Ponadto gromadził oszczędności, gdyż uczniowie pochodzący z bogatych domów przestrzegali tradycji napiwków. Pieniądze przeznaczał między innymi na wyjścia do słynnego Teatru Wołkowskiego.

Należy dodać, że niezwykle barwny język autora sprawia, iż czytelnicy, zagłębiając się w akapity poświęcone temu okresowi, mogą niemal odczuć atmosferę 
tamtych lat i wziąć udział w życiu dość prostej grupy społecznej, w tym jej ucztach duchowych, na które mogła sobie czasem pozwolić. Wypada podkreślić, że chodzenie do teatru, które wynikało nie tylko z chęci udziału w życiu towarzyskim, ale przede wszystkim z własnych potrzeb, wówczas określało człowieka i było swego rodzaju symbolem przynależności do określonej grupy społecznej. Niestety poziom życia właściwy Rosji carskiej wkrótce się zmienił. Autor pisze dalej, że po obaleniu cara Mikołaja II ukochane przez niego teatry stały się sceną agitacji, wręcz wieców popleczników Kiereńskiego, Lenina i innych. Zwycięstwo bolszewików oznaczało dla niego koniec ,pańskich manier” i potrzeb ich zaspokajania, a w gimnazjum brak uczniów w jadalni, a następnie jego zwolnienie z pracy. Bolszewicy triumfowali, głosili hasła równości i likwidacji biedy. Tymczasem właśnie brak pracy i bieda spowodowały, że zaczął pukać do rozmaitych drzwi w poszukiwaniu zatrudnienia. Nabyta w carskiej armii umiejętność kaligrafii sprawiła, że przez pewien czas pracował na stanowisku urzędnika w kopalni węgla w Czelabińsku. Rychło został jednak powołany do służby w Armii Czerwonej i jako piśmienny wysłany do pracy w Departamencie Ochrony Kolei w Omsku. Umowy międzynarodowe i wynikające z nich regulacje granic spowodowały, że w 1921 roku został jednocześnie zdemobilizowany i pozostał sam, bez rodziny. Po traktacie w Rydze rodzinna wieś stała się częścią Polski, a jego bliscy obywatelami II RP. Pozbawiony zatrudnienia, bez pieniędzy, nie mając się dokąd udać, zaczął głodować. Osiedlił się poza miastem i aby przeżyć, kradł ziemniaki z pól. Nie ustając w poszukiwaniu pracy, dowiedział się o werbunku osób piśmiennych do pracy w policji. Po sprawdzeniu dokumentów został przyjęty i w ten sposób rozpoczął się nowy rozdział w jego życiu — jako funkcjonariusza służb.

Na skutek zbiegu okoliczności objął stanowisko komisarza rejonu kojdanowskie$\mathrm{go}^{1}$, leżącego w okręgu mińskim. Szybko zorientował się, że jego praca ma niestety mało wspólnego ze służbą prawu. Kierując się własnym systemem wartości, gdy nie potrafił ukarać ojca ubogiej, wielodzietnej rodziny, który aby pozyskać dodatkowe fundusze, pędził bimber, na skutek donosu został zwolniony z policji pod zarzutem przyjęcia łapówki. Jego współpraca ze służbami jednak się nie zakończyła. Przełożeni, wiedząc o jego prawości i jednocześnie licząc na jeszcze większe oddanie na skutek okazanej łaski, zapewnili mu zatrudnienie jako rezydent GPU (następnie KGB). Po szkoleniu mającym na celu nabycie umiejętności prowadzenia działań wywiadowczych i agitacyjnych został zainstalowany w Bobrujsku. Działając w terenie, udało mu się wykryć tajną organizację nacjonalistyczno-syjonistyczną. Kolejnymi zadaniami były identyfikowanie i wskazywanie oficerów białej armii, którzy z fałszywymi dokumentami starali się zaszyć w rozmaitych miejscowościach, oraz usuwanie nieefektywnych agentów i zastępowanie ich odpowiednimi, tak aby każde przedsiębiorstwo i każda wieś podległego mu rejonu były pod obserwacją. Celem ukrycia działalności został on mianowany przez Radę Komisarzy Ludowych szefem okręgowego komitetu wykonawczego. Po pewnym czasie został przyjęty do oficjalnej służby jako pracow-

1 Główne miasto rejonu, Kojdanów, w 1932 roku zostało przemianowane na Dzierżyńsk na cześć Feliksa Dzierżyńskiego i stało się jednocześnie stolicą Polskiego Rejonu Narodowego im. Feliksa Dzierżyńskiego — autonomicznej polskiej jednostki administracyjnej.

Wrocławskie Studia Wschodnie 24, 2020

(C) for this edition by CNS 
nik wydziału poszukiwań operacyjnych. Od tego momentu, jak pisze, niejako wszedł w konflikt z własnym sumieniem.

Czytelnik, śledząc kolejne akapity, może zadać sobie pytanie, czy warto czytać dalej. W jakim stopniu autor był narzędziem zmuszonym wykonywać rozkazy dowódców, a w jakim we wspomnieniach stara się wybielić? To tylko niektóre pytania, które w tym momencie mogą nurtować zainteresowanych losami Józefa Jatczeni. Nie powinny one jednak podważać zasadności dalszej lektury. $Z$ reguły mamy bowiem do czynienia z publikacjami przedstawiającymi aparat represji z punktu widzenia ofiar spoza grona jego pracowników, a w tym wypadku możemy śledzić los i refleksje człowieka będącego w służbie NKWD, wiedzącego o metodach jego działania.

Jako funkcjonariusz GPU Józef Jatczenia był świadkiem preparowania wielu spraw. Widział, jak jego koledzy awansują, wymuszając zeznania nieprawdy. Były to kariery okupione cierpieniem i nierzadko śmiercią niewinnych ludzi. W kontekście wymuszania zeznań trudno orzec, czy autor się wybiela. W swoich pamiętnikach krytykuje metody „pracy” kolegów, a nawet zamysł kolektywizacji. Zaznacza, że ze względu na uczciwość popadał w niełaskę w miejscu pracy. Jako przykład podawanych informacji opisuje działania komisarza Fedorowicza. Chcąc awansować, rozpoczął on dochodzenie mające na celu wykazanie istnienia tajnej organizacji powstańczej. Jej trzonem miała być ludność czterech wsi w powiecie pińskim, która otwarcie wyrażała niezadowolenie z systemu kołchozowego i samorządu lokalnego. On także bezwiednie brał udział w tej akcji. Został wysłany do jednej z wsi celem przeszukania i aresztowania członka organizacji. Podczas prowadzonych czynności śledczych znalazł broń, choć jak pisze, czuł, że ją podrzucono, ale bał się cokolwiek powiedzieć. Na skutek znalezienia „dowodów” aresztowano wówczas 82 niepiśmiennych chłopów. W ciągu trzech miesięcy ,pracy” z zatrzymanymi wszyscy przyznali się, że należeli do buntowniczej organizacji. Prości ludzie, niepotrafiący przeczytać podanych im do podpisu zeznań, zostali skazani na rozmaite wyroki. Ich oprawcy Fedorowicz i Kaufman otrzymali pracę w centrali w Mińsku. Po ich wyjeździe na skutek raportu jednego z agentów o nazwisku Szumski autor odkrył, że to ten agent na rozkaz wymienionej dwójki podrzucił broń z magazynu wydziału. Zapewne nie był to jedyny przypadek udziału autora w sfingowanej sprawie. Jak sam pisze, wspominając wydarzenia z przeszłości, nie raz był w kłopotliwej sytuacji. Choć milczał, jego brak zaangażowania sprawił, że koledzy uważali go za niewygodnego i zaczęli szukać pretekstu do jego usunięcia.

Okazją do aresztowania Józefa Jatczeni stały się działania organów represji, które rozpoczął dekret umożliwiający aresztowania pod zarzutem prowadzenia pracy agenturalnej między innymi wielu niewinnych osób mających bliskich poza granicami sowieckiej Rosji. Ponieważ rodzina autora mieszkająca w Polsce nie mogła być objęta pracą śledczą, koledzy postanowili się posłużyć bliskimi jego żony, Polki, Katarzyny Zujewskiej. NKWD aresztowało i straciło w Orszy czterech jej braci. Należy dodać, że w Orszy w dawnym kolegium jezuickim mieściło się więzienie, z którego wiele osób nie powróciło do bliskich. Podczas budowy linii kolejowej w 1982 roku odkryto miejsce pochówku 50 aresztowanych, zabitych strzałem w tył głowy. Od sierpnia 2019 roku z inicjatywy potomków zamordowanych działa strona 
internetowa Kobylaki.by, na której dotąd zamieszczono 1750 nazwisk rozstrzelanych, wśród nich 505 Polaków, oraz mapę okręgów ich miejsc zamieszkania przed aresztowaniem. Osoby skupione wokół strony i inicjatywy „Kobylaki. Rozstrzelani w Orszy" pomagają zainteresowanym w uzyskaniu dokumentów z archiwów KGB i dbają o miejsce spoczynku pomordowanych. One też umieściły na stronie nazwiska zamordowanych z rodziny Zujewskich i pomogły ich bliskim w uzyskaniu dokumentów dotyczących zamordowania aresztowanych.

Oskarżony o szpiegostwo na rzecz Polski Józef Jatczenia został umieszczony $\mathrm{w}$ więzieniu wewnętrznym, tak zwanej amerykance. Został tam poddany wyjątkowo brutalnym i wymyślnym torturom przez śledczego, sadystę Klimowicza. Autor, wspominając tamten czas, w sposób bardzo sugestywny, posługując się językiem zrównoważonym, pełnym dystansu do wydarzeń i cierpienia, które było jego udziałem, pisze: „W celi nie było nic ciekawego poza wypisanym napisem na ścianie: »Bili mnie, szydzą, okaleczają na nic... Nie wiecie, co to jest wstawać każdego ranka i czekać, aż dziś zostaniecie zabici... Czekam. Jak czeka worek węgla, zanim wrzuci się go do pieca«" (s. 122). Choć nalegano, aby przyznał się do winy i wskazał agentów, nad którymi miał nadzór, nie zrobił tego. Klimowicz ,pracował” z nim od października 1937 do września 1938 roku. Bity, wsadzany do karceru, ponownie torturowany, „doprowadzany był do porządku” w szpitalu, po czym „pracę” z nim wznawiano. Autor zaznacza, że Klimowicz kochał swoją pracę i bardzo mu zależało, aby podpisał zeznania, że jest rezydentem polskiego wywiadu. Złamanie go oznaczało dla tego człowieka ,zasłużony” awans i inne wyróżnienia. Pomimo tortur Jatczenia niczego nie podpisał. $Z$ doświadczenia wiedział, że nie może podpisać, gdyż to oznaczało śmierć, a on chciał żyć. Do przeżycia autora przyczyniła się zmiana sytuacji wewnętrznej w kraju. Usunięcie ze stanowiska komisarza ludowego bezpieczeństwa państwowego Nikołaja Jeżowa sprawiło, że represje zelżały. Jatczenia znalazł się z grupie tych, którzy mimo tortur nie przyznali się do winy, a więc potencjalnie byli niewinni. Został zwolniony $\mathrm{z}$ więzienia $\mathrm{z}$ zakazem przebywania $\mathrm{w}$ pasie przygranicznym obejmującym odległość $100 \mathrm{~km}$. Wyjście na wolność autor wspomina jako drugie narodziny.

Doświadczenie ,amerykanki” nauczyło go, że byle pretekst wystarczy, aby został ponownie aresztowany. Sprzyjało temu odczuwalne napięcie związane z wojną 1939 roku. Po przyłączeniu do ZSRS byłych polskich Kresów Wschodnich, chcąc zniknąć $\mathrm{z}$ bezpośredniego pola widzenia, wyjechał $\mathrm{z}$ bliskimi w rodzinne strony. Miał nadzieję, że tam nic nie będzie o nim wiadomo. Udało mu się nawet uzyskać pracę księgowego w administracji powiatu. Problem polegał jednak na tym, że był „człowiekiem niepewnym" nie tylko dla komunistów, lecz także dla Niemców, gdyż służył NKWD. Przenosiny do rodzinnej wsi, którą wkrótce objęli we władanie Niemcy, nie dawały już ochrony. Podjął więc decyzję o udaniu się do partyzantów.

$\mathrm{W}$ rozdziale dotyczącym życia codziennego partyzantów czytelnik znajdzie informacje odbiegające od powszechnej narracji bohaterskiej partyzantki sowieckiej. Życie autora $\mathrm{w}$ lesie jest bowiem dla niego źródłem nowych, niespodziewanych sytuacji, które były zapewne nie tylko jego udziałem. Na skutek braku zorganizowanego zaopatrzenia partyzanci byli skazani na utrzymanie kosztem chłopów. Niestety nie wszyscy prosili o niezbędne rzeczy. Wielu grabiło i zabierało rzeczy nawet ponad miarę potrzeb. 
Niektórzy, tak zwani zapobiegliwi, ukrywali łupy w lesie. Autor opisuje szabrownictwo grupy, do której trafił. Następnie przeniósł się do innej. Niestety jak wspomina, jego dowódca okazał się alkoholikiem i porywaczem. Demoralizacja była powszechna. Dowódcy pili i zmieniali tak zwane partyzanckie żony. Brali kobiety swoich partyzantów i wymieniali je na bimber. Dopiero przejście frontu i ogłoszenie mobilizacji do Armii Czerwonej zmieniło sytuację. Józef Jatczenia miał szczęście. Jako piśmienny nie trafił do jednostek liniowych, lecz dostał pracę w biurze. $Z$ pracą w biurze był już związany do czasu przejścia na emeryturę. Ironia losu sprawiła, że w czasach powojennych korzystał z szacunku okazywanego partyzantom.

Józef Jatczenia, podsumowując to, co widział, podejmuje próbę analizy, dlaczego służył oprawcom, a następnie był ich ofiarą, niejako szuka odpowiedzi, czy zrobił coś dobrego i co zrobił źle. Idąc śladem jego refleksji, można podejrzewać, że jak każdy człowiek wybiela swoje czyny. Ale czy możliwy brak obiektywizmu, zgodny przecież z ludzką naturą, dewaluuje jego wspomnienia? Na pewno nie. Są one wyjątkowe, po raz pierwszy mamy do czynienia z obrazem trudnych czasów widzianych jednocześnie oczyma kata i ofiary. Opisywane wydarzenia i przeżycia autora są materiałem do podjęcia refleksji dotyczącej motywów działań człowieka pozostającego pod wpływem systemu państwowego, politycznego i związanych z nimi rozmaitych determinantów, grup nacisku. Mogą być przyczynkiem do prób odpowiedzi na pytania o skalę wpływu systemu władzy na ludzi, którzy z natury nie są źli, nie są sadystami. Na pewno niewiele osób stać, aby się przeciwstawić zbrodniczym działaniom systemu. Chęć przeżycia, milczenie robi z nich sojuszników. Wobec tego za cel przyświecający spisaniu wspomnień przez autora można uznać chęć zwrócenia uwagi wnuka i młodszego pokolenia na to, co kryje się za propagandą i słowami ideologów, pokazanie przez pryzmat własnych doświadczeń, że w czasach carskich oficerowie i członkowie rodzin dobrze urodzonych byli warstwą uprzywilejowaną, w odróżnieniu od robotników i chłopów skazanych na życie w prymitywnych warunkach. Pokazanie, że niemal nic się nie zmieniło w czasach sowieckich, oficerowie i osoby urodzone we właściwych rodzinach tak samo korzystali z przywilejów dostępnych tylko im, w tym sklepów z rozmaitymi artykułami, w odróżnieniu od reszty społeczeństwa.

Należy podkreślić, że dodatkowym walorem przedstawianej książki jest weryfikacja wspomnień podjęta przez opracowującą je do druku dziennikarkę Anastazję Zielenkową. Próba odnalezienia dokumentów potwierdzających prawdziwość słów autora, dzięki rodzinie i współpracy archiwistów, w odniesieniu do wymienionych we wspomnieniach osób oraz wydarzeń przyniosła pozytywny efekt. Ze względu na walory faktograficzne oraz przystępny język narracji omawianą książkę można uznać za interesującą i polecić jako lekturę zarówno badaczom tematu represji stalinowskich, jak i czytelnikom, którzy są zainteresowani popularnym spojrzeniem na historycznie wydarzenia XX wieku oczami bezpośredniego uczestnika. 